\title{
Critical Study of Sociocultural Practice in Cattle Trading Arena
}

\author{
Sujarwa $^{a, 1^{*}}$, Andrik Purwasito ${ }^{\mathrm{b}}$, Sri Kusuma Habsari ${ }^{\mathrm{c}}$, Titis Srimuda Pitana ${ }^{\mathrm{d}}$ \\ aProdi Sastra Indonesia, Universitas Ahmad Dahlan, ${ }^{\mathrm{b}, \mathrm{c}, \mathrm{d}}$ Universitas Sebelas Maret Surakarta \\ Email: 'sujarwa.123_8@student.uns.ac.id*; Sujarwa.uad@gmail.com \\ *corresponding author
}

Keywords:

Critical, Discourse, Sociocultural,

Style, Register

\begin{abstract}
In the cattle trading arena, it is suspected that there is a peculiarity of registers as a style and rhetorical discourse of disguised communication as a form of tactics, which is not in line between linguistic aspects and sociocultural behavior. Register as a rhetorical style of communication is built, of course not without reason, but there is motivation, intention, and achievement of communication goals. This paper attempts to reveal: the form of registers in the rhetoric of communication in the cattle trading arena, the function of the register as communication rhetoric in the cattle trading arena, the symbolic meaning of registers in the rhetorical style and discourse of sociocultural practice in the cattle trading arena. A qualitative descriptive method is used to describe substantially the aspects of the meaning of the data with an in-depth analysis related to the subject matter. In order to achieve a profound interpretation, theoretical aids are needed: sociocultural, sociolinguistic, stylistic, capitalism, hegemony, discourse theory. In addition, hermeneutic theory as a strategic method for understanding texts must be interpreted for meaning. The results showed: the form of registers in the rhetoric of communication in the cattle trading arena in the form of oratorical, deliberative, consultative, casual, and intimate. The study concludes that the register functions as a conative and emotive tactic to influence, weaken, subdue, and restrain hegemony from creating an atmosphere of domination. The register applied in the rhetoric of communication in the cattle trading arena contains the symbolic meaning of feudalism relations in the form of phenomena of sociocultural practice events influenced by the discourse of tactics for capitalist cultural domination.
\end{abstract}

This is an open access article under the CC-BY-SA license. Copyright $(\subset) 2021$ Channel Jurnal Komunikasi. All right reserved.

\section{INTRODUCTION}

The researchers are interested in seeing the form of rhetoric communication in the cross-cultural practice of the cattle trading arena as a material object, while the formal object of the registers in the style and discourse of communication rhetoric. Registering in the style and discourse of rhetoric communication in the cattle trading arena is considered attractive to research because of the diverse forms with arenas built by diverse habits. The arena is often political jargon. The roles of a negative connotation event model that is rarely examined; The roles of such an event model is now a lot of reference models, whose space is no longer limited in the arena of cows but extends to public media, which can be in the form of print, radio, television, and social media.

This study needs linguistic assistance, especially sociolinguistics. According to Suwito (1985), sociolinguistics is seen as a multidisciplinary science, meaning that being domiciled as an independent discipline as a language study also involves other scientific disciplines. Sociolinguistics views language as a social system and communication system of certain parts of society and culture.

Language usage is a form of social interaction that occurs in concrete situations. This discussion seeks to know cultural practices in the cattle trading arena that utilize communication rhetoric's style and discourse as a means of communication. A communication process is a form of direct social interaction that occurs in concrete situations. Studies 
studying languages as verbal interaction systems between speakers in the community by Suwito (1985) are called interactional sociolinguistics or macro sociolinguistics.

The register is a variety of languages based on its use, namely, the language used depends on what is being done and the nature of its activities (Halliday, 1994). It stressed that the use of register in the rhetoric communication of cattle commercialities could uncover other aspects of his social context because it included social activities involving many people in the social process. For this, registers can be understood as a semantic concept, namely as a means of meaning associated explicitly with specific situations. Furthermore, Halliday explained the concept of the situation as follows.

As in the cattle trading arena, the style and discourse of communication rhetoric given symbolic meaning will be understood when the language implementation or symbols refer to the three things, the concept of seating. The existence of Medan, peel rates, and facilities need to be understood as things that must be interpreted by symbolic meaning according to its activities and arts. The utilization of registers as the theory in this study to find out various things involving: forms of registers, register functions, and the meaning of registers for speakers and other phenomena related to socio-cultural practice activities of the society.

According to Aminuddin (1995), style is the technique and form of a person's language style in presenting ideas following the ideas and norms used as personal wearers. In the rhetorical situation of cattle trade communication, the use of language styles in figurative language can be varied because it includes many people. The term style of language is not referred to as a complete form of language as a discourse but rather to words and speech units that are considered to contain beauty. Therefore, the studies have focused more on units of expression independently, not on their textual relationships.

Awareness about this shows that the rhetoric that describes the language style of market participants can also vary, both in terms of the level of speakers and the type of language style used by market participants when making rhetoric. In this case, Keraf (1990) divides language styles into 22 kinds, but the author sees that not all of the 22 language styles are used in the rhetoric of communication in the cattle trading arena, so it is suspected that there are things that are unique or special in that arena. This peculiarity can be seen in the style of the language spoken by the actors involved.

Rhetoric comes from the English "rhetoric" and the Latin word "rhetoric," which means speech science. Rhetoric has rational, empirical, general, and accumulative properties (Harsoyo in Susanto, 1988). Rhetoric is seen as a science in speaking so that it has empirical, rational, general, and accumulative properties. As a science of speaking, rhetoric is not distinguished from communication, because in general, rhetoric is considered the art of using language effectively, so that it is often equated with public speaking or the ability to speak in public. According to Aristotle, rhetoric in communication is seen as having its purpose, as stated in the following quote.

The cattle trading arena as an event of socio-cultural practice is seen as a reflection of the community's sociocultural phenomenon. Events of socio-cultural practice in the cattle trading arena are suspected to be a struggle between two opposing forces to compete for power. The two forces are between the investors, who are seen as superior, and the traditional farming community, which is seen as inferior as it is known that investors are those who are seen as having more capital, which can be in the form of social capital, economic capital, cultural capital, information capital, and symbolic capital. It shows that investors can be translated in various forms, which in each form of capital can include various other forms and each type of capital ownership is often perceived and recognized for its legitimacy in sociocultural practice. The same thing is found in the component of investors in the cattle trading arena. What is interesting in this arena is that there is a rhetoric of communication that investors always build with more capital to marginalize the existence of traditional breeders. Such communication rhetoric is undoubtedly not without pretense and meaning but contains messages of symbolic meaning that need to be understood in terms of its socio-cultural significance.

The socio-cultural practice of the cattle trading arena as a rhetoric arena of communication charged forces and symbolic discourse. The study places the entire complexity of the interrelation of the form of knowledge with nondiscursive practices and discursive practices, namely knowledge, power, and social institutions, as a medium to operate the mechanism of power and the form of knowledge that consolidates it.

Research efforts on rhetorical communication styles and discourses have been carried out, including the following. First, Sutrisno and Wiendijarti (2015) focused on the usefulness aspect of rhetoric. This study uses a qualitative descriptive method, the object of which is a literature review of the rhetorical theory of Aristotle and Cicero. The formal object is the role and function of rhetoric for the development of knowledge and skills. It is different from the author's research which prioritizes register studies in the rhetorical style and discourse of communication in direct socio-cultural practice, namely the cattle trading arena. In other words, both material objects and formal objects and theories are different so that this study can be seen as having novelty in terms of the subject matter, arena or material object, and multidisciplinary theory.

The second is the research of Alberico and Loisa (2019) uses social media material objects, with the formal object being the use of deliberative rhetoric by Benazir. The method used is a qualitative case study. The results of his research conclude that the deliberative rhetoric carried out by the celebrity, Benazir, is based on experience and is frank. 
The third is the research of Martha (2010), viewing rhetoric as a science and the study of speaking skills. In its development, rhetoric is used in various areas of life, namely: politics, business, art, journalism, and education. The audience or interlocutor strongly influences the ability to use language rhetoric.

The research by Imron Hadi (2017) determined the object of the language studied and analyzed descriptively to describe the situation that occurred. Data was obtained through recording and interview techniques. The analysis results show three types of registers used, namely, consultative, intimate, and deliberative. Then, the register functions used include informative, personal or personal closeness, interactive, and instrumental functions. From the analysis results, it can be concluded that fruit traders use certain types and functions of registers based on the variety or type of fruit they sell.

Another register study with similarities in terms of subject matter and methods but different material objects is Sudaryanto et al. (2013), which used a descriptive qualitative method. Sources of data are speech events of street children and informants. Data collection techniques used direct observation, interviews, and recording the dialogue of street children. The research concludes that the unique characteristics and objectives of registering street children are different from the characteristics and objectives of other communities or community groups.

Departing from the relevant research tracking above, in the meantime, the author can say research on the style and discourse of rhetoric communication in the cattle trading arena has not been done. All existing research models are still normative, meaning focusing more on the arena of formal institutions and regions of conventional relations. It is different from the rhetoric of contraception used in the socio-cultural practice area directly in public spaces such as the cattle trading arena. They can uncover the facts of the authentic culture of language speakers and see the phenomenon behind the visible, hidden as a mirror of society's cultural mentality or socio-cultural phenomena.

\section{METHOD}

As delivered initially, this study will reveal the style and discourse of communication rhetoric in the cattle trading arena. In other words, the material object of this study is in the form of a cattle trading arena as a sociocultural practice area. Meanwhile, the object of study is the style and discourse of communication rhetoric in the arena. So, this research material is the style and discourse, which is a speech of the actors involved in the cattle trading arena. Thus, this study is a field study, the data material obtained from the field is based on surveys, observations, and interviews. As for the form of a bat, it was said between the actors of the financial transaction process. Thus, the material can be in the form of words, phrases, sentences, discourse, and other symbols that are referred to in the arena-all data obtained by the research location in the cattle trading arena in Magelang Regency. However, its location does not rule out the possibility of occurring in cages of farmers, stalls, social media such as WA because, in the modern era like now, communication can be done anywhere with communication technology devices.

The primary data source in this study were all speeches and discourse of communication rhetoric originating from the community involved in the cattle trading arena. According to Lofland (1984) in Moleong (1991), it was said that everything that accompanied the fertilizer in the form of words and actions could be said to be qualitative data. In other words, this type of study is descriptive qualitative; the data source is obtained from the field as the quote above. According to Whitney (1960), the descriptive method is a fact search for the correct interpretation. The move can be said as qualitative research if it is intended to understand the phenomena experienced by research subjects, such as behavior, perception, motivation, and other actions, which holistically and descriptions can be in the form of words and languages, which are carried out in a unique context nature and by utilizing the natural method.

The discussion using qualitative content analysis), which is aimed at producing the findings of the style and discourse of communication rhetoric in the cattle trading arena, is qualitatively interpreted as a phenomenon. According to Moleong (1991), qualitative research is a social science tradition that is fundamentally dependent on human observation in its region and relates to these people in their language and tenement. This study also uses a descriptive approach, namely the study conducted solely based on existing facts or empirical phenomena, so what is produced is recorded in the form of fermented sentences commonly said such as portrait or writing. Description research is the basis for all scientific investigations, with the preparation of descriptive information including Activities listening, grouping (classifying) a series of elements seen as a forming of a current issue (Black, 1992).

This study will collect data or information using interactive and not inactive methods tailored to the research problem. Following the type of qualitative research, the main instrument of data collection is the researcher supported by other appropriate instruments. The supporting techniques and instruments used in data collection include a set of recording devices, cellphones, tape recorders, and data cards to conduct in-depth interviews (in-depth interviews); Participatory observation; Survey Content Analysis; Focus Group Discussion (FGD).

The level of truth or validity of the problem in this study is determined by the Triangulation method. Namely, the technique of examining data validity utilizes something outside the data for data comparison. Four kinds of standard 
triangulation use sources, methods, researchers, and theories (Moleong, 1991). C.6. Data analysis technique This research data were analyzed inductively using interactive analysis methods from Miles and Gadermen (1984) in the form of data collection, data reduction, data presentation, and verification or conclusion withdrawal stages. The interactive model of the third activity analysis is a cycle process and is interactive. Each stage of the activity is done separately but can run

together and complement each other.

\section{RESULTS AND DISCUSSION}

Table 1. Register in the Communication Rhetoric of the Cattle Trading Arena

\begin{tabular}{|c|c|c|c|c|c|}
\hline No. & Speech Discourse Data & Meaning of Speech & Register Form & $\begin{array}{l}\text { Kinds of } \\
\text { Register }\end{array}$ & Register Function \\
\hline 1. & $\begin{array}{l}\text { "Monggo Pak silahkan } \\
\text { dipresani ! Ini barangnya isti- } \\
\text { mewa semua." } \\
\text { "Please, sir, please order! } \\
\text { These are all special." }\end{array}$ & $\begin{array}{l}\text { Manipulate and regulate } \\
\text { the condition of the } \\
\text { interlocutor to follow } \\
\text { the speaker's wishes by } \\
\text { discussing the condition of } \\
\text { the goods. }\end{array}$ & $\begin{array}{l}\text { Oratorical or } \\
\text { frozen in formal, } \\
\text { deliberative } \\
\text { situations }\end{array}$ & Open-loop & $\begin{array}{l}\text { Instrumental, } \\
\text { conative information }\end{array}$ \\
\hline 2. & $\begin{array}{l}\text { "Ini bakalan murah hanya } \\
11 \text { jt-an kema } \neg \text { rin sudah } \\
\text { ditawar Pak Haji } 10 \text { jt tapi } \\
\text { masih saya tahan, kalau untuk } \\
\text { Jenengan } 11 \text { jt aja boleh untuk } \\
\text { me } \neg \text { nyambung relasi." } \\
\text { "This will be cheap, only } 11 \\
\text { million yesterday, Pak Haji } \\
\text { offered } 10 \text { million, but I am } \\
\text { still holding it. If it is only } 11 \\
\text { million for you, it is okay to } \\
\text { continue the relationship." }\end{array}$ & $\begin{array}{l}\text { Manipulation and } \\
\text { managing the condition of } \\
\text { the interlocutor to follow } \\
\text { the speaker is woven with } \\
\text { feudalistic relations as a } \\
\text { stratagem effort. }\end{array}$ & $\begin{array}{l}\text { Consultative or } \\
\text { business, casual or } \\
\text { casual, intimate, } \\
\text { intimate }\end{array}$ & $\begin{array}{l}\text { Open-loop and } \\
\text { closed-loop }\end{array}$ & closed-loop \\
\hline 3. & $\begin{array}{l}\text { "Now it's hard to find this } \\
\text { kind of cow, not everyone has } \\
\text { it, so the price is pretty good." } \\
\text { "Sekarang cari bakalan jenis } \\
\text { macam ini susah, tidak semua } \\
\text { orang punya maka harganya ya } \\
\text { lumayan" }\end{array}$ & $\begin{array}{l}\text { Manipulating the situation } \\
\text { to regulate the condition of } \\
\text { the interlocutor following } \\
\text { the speaker. }\end{array}$ & $\begin{array}{l}\text { Consultative or } \\
\text { business, causal and } \\
\text { casual, regulatory }\end{array}$ & Open-loop & $\begin{array}{l}\text { Instrumental, } \\
\text { neuritic, imaginary } \\
\text { or imaginative } \\
\text { and informative, } \\
\text { conative, } \\
\text { representational }\end{array}$ \\
\hline 4. & $\begin{array}{l}\text { "This is a good item, but } \\
\text { unfortunately the color is } \\
\text { black, usually it weighs less" } \\
\text { "Ini barang bagus tapi sayang } \\
\text { ya warnanya hitam biasanya } \\
\text { bobot-nya kurang" }\end{array}$ & $\begin{array}{l}\text { Efforts to circumvent } \\
\text { the interlocutor with } \\
\text { metalingual and nephritic } \\
\text { markers. }\end{array}$ & $\begin{array}{l}\text { Oratorical } \\
\text { consultative and } \\
\text { causal. }\end{array}$ & Open-loop & $\begin{array}{l}\text { Poetic, metalingual, } \\
\text { imagination, } \\
\text { emotive. }\end{array}$ \\
\hline 5. & $\begin{array}{l}\text { "This is a quiet condition, but } \\
\text { it's okay with you, I'll pay in } \\
\text { cash as long as the price is that } \\
\text { much." } \\
\text { "Ini kondisi lagi sepi tapi } \\
\text { tidak apa sama Jenengan } \\
\text { nanti saya bayar kontan asal } \\
\text { harganya segitu." }\end{array}$ & $\begin{array}{l}\text { Manipulation of the } \\
\text { situation with the tactic of } \\
\text { being intimate. }\end{array}$ & $\begin{array}{l}\text { Consultative, causal, } \\
\text { intimate }\end{array}$ & Open-loop & $\begin{array}{l}\text { Instrumental, } \\
\text { interaction, } \\
\text { personal, neurotic, } \\
\text { emotive, conative }\end{array}$ \\
\hline 6. & $\begin{array}{l}\text { "What do you use for this } \\
\text { cow? Fat but less dense.." } \\
\text { "Ini sapinya komboran } \\
\text { ya pakai apa? Gemuk tapi } \\
\text { kurang padat ya dagingnya." }\end{array}$ & $\begin{array}{l}\text { Poetic tactics and } \\
\text { manipulation of the } \\
\text { situation. }\end{array}$ & Consultative, casual & Open-loop & $\begin{array}{l}\text { Poetic, imagination, } \\
\text { emotive and } \\
\text { conative. }\end{array}$ \\
\hline
\end{tabular}




\begin{tabular}{|c|c|c|c|c|c|}
\hline 7. & $\begin{array}{l}\text { "Please sir, can I help you?" } \\
\text { "Silahkan Pak ada yang bisa } \\
\text { saya bantu?" }\end{array}$ & Emotive and fatigue tactics. & $\begin{array}{l}\text { Oratorical, } \\
\text { deliberative, } \\
\text { consultative }\end{array}$ & Open-loop & $\begin{array}{l}\text { Referential, } \\
\text { emotive, conative }\end{array}$ \\
\hline 8. & $\begin{array}{l}\text { "Here, you can join any } \\
\text { program, each has its own } \\
\text { rules. Just choose which } \\
\text { one you like and can afford } \\
\text { according to your business } \\
\text { capacity" } \\
\text { "Di sini boleh mengikuti } \\
\text { program mana saja, masing- } \\
\text { masing ada aturannya } \\
\text { sendiri. Tinggal pilih mana } \\
\text { yang Bapak suka dan mampu } \\
\text { sesuai dengan kapasitas usaha } \\
\text { Anda" }\end{array}$ & $\begin{array}{l}\text { Formal information } \\
\text { efforts and efforts to } \\
\text { convey certain messages } \\
\text { with strategies to solve } \\
\text { problems. }\end{array}$ & $\begin{array}{l}\text { Oratorical, } \\
\text { deliberative, } \\
\text { consultative }\end{array}$ & Open-loop & $\begin{array}{l}\text { Referential, } \\
\text { poetic, emotive } \\
\text { and conative } \\
\text { information. }\end{array}$ \\
\hline 9. & $\begin{array}{l}\text { "Excuse me, sir, if you take } \\
\text { part in this one program, it } \\
\text { is indeed good but all the } \\
\text { requirements must be met as } \\
\text { in the flyer." } \\
\text { "Nyuwun sewu Pak, kalau } \\
\text { Bapak mengikuti program } \\
\text { yang satu ini memang enak } \\
\text { tapi persyaratannya harus } \\
\text { dipenuhi semua seperti } \\
\text { dalam liflet itu." }\end{array}$ & $\begin{array}{l}\text { Formal information } \\
\text { efforts and efforts to } \\
\text { convey certain messages } \\
\text { with tactics to divert and } \\
\text { influence t-tour opponents } \\
\text { to follow their directions as } \\
\text { customers. }\end{array}$ & $\begin{array}{l}\text { Oratorical, formal, } \\
\text { consultative }\end{array}$ & Open-loop & $\begin{array}{l}\text { Referential, } \\
\text { poetic, emotive } \\
\text { and conative } \\
\text { information. }\end{array}$ \\
\hline 10. & $\begin{array}{l}\text { "Excuse me, sir, how many } \\
\text { cows are there now. Do the } \\
\text { animals often give medicine } \\
\text { or injections, sir? Because if } \\
\text { you eat only grass, you can get } \\
\text { worms, and the cage must also } \\
\text { be clean!" } \\
\text { "Maaf Pak, ada berapa } \\
\text { ekor sekarang sapinya Apa } \\
\text { hewannya sering dikasih } \\
\text { obat atau di-suntikan Pak? } \\
\text { Karena kalau makannya } \\
\text { seba-tas rumput bisa jadi ada } \\
\text { cacingnya, dan kandang juga } \\
\text { harus bersih!" }\end{array}$ & $\begin{array}{l}\text { Formal information efforts } \\
\text { and efforts to deliver } \\
\text { command messages so that } \\
\text { the interlocutor follows } \\
\text { the direction of reporting } \\
\text { their activities. There are } \\
\text { tactical efforts to find data } \\
\text { for reports. }\end{array}$ & Oratorical, formal & Open-loop & $\begin{array}{l}\text { Referential, poetic, } \\
\text { informational, } \\
\text { emotive and } \\
\text { conative. }\end{array}$ \\
\hline
\end{tabular}

Table 2. The Function of the Register in the Rhetoric of Cattle Commerce Communication

\begin{tabular}{cll}
\hline No. & \multicolumn{2}{c}{ The Function of the Register in the Rhetoric of Cattle Commercial Communication } \\
\cline { 2 - 3 } & \multicolumn{1}{c}{ Register Name } & \multicolumn{1}{c}{ Register Function } \\
\hline 1 & Instrumental, conative information & $\begin{array}{l}\text { Manipulate and regulate the condition of the interlocutor to follow } \\
\text { the speaker's wishes by discussing the condition of the goods. }\end{array}$ \\
\hline 2 & $\begin{array}{l}\text { Instrumental, regulatory, representational, } \\
\text { interactional, imaginative }\end{array}$ & $\begin{array}{l}\text { Manipulation and regulating the condition of the interlocutor to } \\
\text { follow the speaker is woven with feudalistic relations as a stratagem } \\
\text { effort }\end{array}$ \\
\hline 3 & $\begin{array}{l}\text { Instrumental, neuritic, imaginary or imaginative and } \\
\text { informational, conative, representational }\end{array}$ & $\begin{array}{l}\text { Manipulating the situation to regulate the condition of the } \\
\text { interlocutor following the speaker. }\end{array}$ \\
\hline 4 & Poetic, metalingual, imagination, emotive. & $\begin{array}{l}\text { Efforts to circumvent the interlocutor with metalingual and neuritic } \\
\text { markers. }\end{array}$ \\
\hline
\end{tabular}




\begin{tabular}{cll}
\hline 5 & $\begin{array}{l}\text { Instrumental, interaction, personal, neurotic, emotive, } \\
\text { conative }\end{array}$ & Manipulation of the situation with the tactic of being intimate. \\
\hline 6 & Poetic, imagination, emotive and conative. & Poetic tactics and manipulation of the situation. \\
\hline 7 & Referential, emotive, conative & Upaya penyiasatan emotif dan fatik. \\
\hline 8 & $\begin{array}{l}\text { Referential, poetic, emotive, and conative } \\
\text { information. }\end{array}$ & $\begin{array}{l}\text { Formal information efforts and efforts to convey certain messages } \\
\text { with strategies to solve problems. }\end{array}$ \\
\hline 9 & $\begin{array}{l}\text { Referential, poetic, emotive, and conative } \\
\text { information. }\end{array}$ & $\begin{array}{l}\text { Formal information efforts and efforts to convey certain messages } \\
\text { with tactics to divert and influence the interlocutor to follow his } \\
\text { direction as a customer. }\end{array}$ \\
\hline 10 & $\begin{array}{l}\text { Referential, poetic, informational, emotive, and } \\
\text { conative. }\end{array}$ & $\begin{array}{l}\text { Formal information efforts and efforts to deliver command } \\
\text { messages so that the interlocutor follows the direction of reporting } \\
\text { their activities. There are tactical efforts to find data for reports. }\end{array}$ \\
\hline
\end{tabular}

Table 3. Register in the Discourse of Strategy

The Rhetoric of Communication in the Cattle Trading Arena

\begin{tabular}{|c|c|c|c|c|}
\hline \multirow[t]{2}{*}{ No. } & \multicolumn{4}{|c|}{ Register in the Discourse of Communication Rhetoric Strategy } \\
\hline & $\begin{array}{c}\text { Breeder and Investor } \\
\text { Relations }\end{array}$ & Register and style & Rhetoric Discourse & Elements of Strategy \\
\hline 1. & $\begin{array}{l}\text { Investors (Banks, } \\
\text { Koperasi) with Breeders }\end{array}$ & $\begin{array}{l}\text { Oratorical, } \\
\text { deliberative, } \\
\text { consultative. }\end{array}$ & $\begin{array}{l}\text { Offering an attractive, easy, } \\
\text { inexpensive system, by looking } \\
\text { at the customer's capacity. }\end{array}$ & $\begin{array}{l}\text { Offers convenience by circumventing } \\
\text { the legitimacy of the more capital capital } \\
\text { system. }\end{array}$ \\
\hline 2. & $\begin{array}{l}\text { Investors (Personal) } \\
\text { with Breeders. }\end{array}$ & $\begin{array}{l}\text { Oratorical, } \\
\text { deliberative, } \\
\text { consultative. }\end{array}$ & $\begin{array}{l}\text { Offering intimate and semi- } \\
\text { official cooperation to bind and } \\
\text { restrain. }\end{array}$ & $\begin{array}{l}\text { Offers convenience by tactics to exploit the } \\
\text { value of the surplus labor of farmers for } \\
\text { investors with more capital. }\end{array}$ \\
\hline 3. & $\begin{array}{l}\text { Government Elements } \\
\text { with Breeders }\end{array}$ & Oratorical, formal & $\begin{array}{l}\text { Ask more questions, and rule in } \\
\text { a simple manner, suggesting. }\end{array}$ & $\begin{array}{l}\text { Offers convenience with the tactic of } \\
\text { cultural symbols and hegemony over } \\
\text { feudalistic relations. }\end{array}$ \\
\hline 4. & $\begin{array}{l}\text { Merchants with } \\
\text { Breeders }\end{array}$ & $\begin{array}{l}\text { Consultative, } \\
\text { casual, intimate }\end{array}$ & $\begin{array}{l}\text { Exaggerating and abusing the } \\
\text { condition of merchandise to } \\
\text { influence, weaken, subjugate, } \\
\text { and restrain }\end{array}$ & $\begin{array}{l}\text { Persuading the situation with the tactics } \\
\text { of logic discourse turns to influence, melt, } \\
\text { subdue, restrain. }\end{array}$ \\
\hline 6. & $\begin{array}{l}\text { Slaughterer financier } \\
\text { with Breeder }\end{array}$ & $\begin{array}{l}\text { Consultative, } \\
\text { casual, intimate }\end{array}$ & $\begin{array}{l}\text { Exaggerating and abusing the } \\
\text { condition of merchandise to } \\
\text { influence, weaken, subdue, and } \\
\text { restrain. }\end{array}$ & $\begin{array}{l}\text { Persuading the situation with the tactics } \\
\text { of logic discourse turns to influence, melt, } \\
\text { subdue, restrain }\end{array}$ \\
\hline 7. & $\begin{array}{l}\text { Blantik Investors with } \\
\text { Breeders }\end{array}$ & $\begin{array}{l}\text { Consultative, } \\
\text { casual, intimate }\end{array}$ & $\begin{array}{l}\text { Exaggerating and abusing the } \\
\text { condition of merchandise to } \\
\text { influence, weaken, subdue, and } \\
\text { restrain. }\end{array}$ & $\begin{array}{l}\text { Persuading the situation with the tactics } \\
\text { of logic discourse turns to influence, melt, } \\
\text { subdue, restrain. }\end{array}$ \\
\hline 8. & Butcher with Breeder & $\begin{array}{l}\text { Consultative, } \\
\text { casual, intimate }\end{array}$ & $\begin{array}{l}\text { Exaggerating the excess or lack } \\
\text { of merchandise with restraining } \\
\text { insults }\end{array}$ & $\begin{array}{l}\text { Persuading the situation with the tactics } \\
\text { of logic discourse turns to influence, melt, } \\
\text { subdue, restrain }\end{array}$ \\
\hline 9. & Cow seller with Farmer & $\begin{array}{l}\text { Consultative, } \\
\text { casual, intimate }\end{array}$ & $\begin{array}{l}\text { Exaggerating the excess or lack } \\
\text { of merchandise with restraining } \\
\text { insults }\end{array}$ & $\begin{array}{l}\text { Persuading the situation with the tactics } \\
\text { of logic discourse turns to influence, melt, } \\
\text { subdue, restrain }\end{array}$ \\
\hline
\end{tabular}

\section{A. Register Form in The Rhetoric of Cattle Trade Communications}

A register is a set of meanings for language users with meanings and purposes relevant to a particular language function. In other words, the register function has a meaning aspect in line with the language function, which is influenced by the situation and the purpose of the communication. As a means of communication, register forms are also as diverse as language function, including words, use of terms, idioms, choice of structures, variety of spoken or written forms, and discourse styles. The existence of registers as a form of communication rhetoric in the cattle trading arena has a distinctive form because it is located in a commercial-oriented public arena.

The existence of registers as a means of rhetorical communication in the cattle trading arena is influenced by many factors, including terrain, involvement, and the facilities used. It requires the actors involved to carefully select registers in line with the existing situation and conditions. The process of using registers as a form of rhetorical communication in the cattle trading arena more often uses consultative, oratorical, deliberative, casual, and intimate or intimate forms. 
All of the registers the actors involved above are not free from pretense, but other hidden things allow them to be studied in depth. The cattle trading arena as a business arena has various involved actors with various backgrounds. Diversity in the arena can be localized into an event of sociocultural practice, marked by linguistic events in the user registers. These linguistic events are a signal of a social phenomenon related to the behavior of the community. As stated in Table 1 above, the study results used consultative, oratorical, deliberative, casual, and intimate registers, which can be traced to their meaning as linguistic events and socially meaningful.

Consultative, causal, intimate, oratorical, deliberative registers are widely used in cattle trading transactions to achieve the desired goal. The rhetoric of communication in the cattle trading arena is colored by the five forms of registers which include many involved, be it the apparatus, financiers, traders, butchers, brokers, and breeders. Due to many parties involved, it involves the correlation between actors involved. Each of which determines its field and means to affect the quality of their rhetoric in communicating.

As shown in Table 1, the registers that the participants widely use are consultative, casual, intimate, whose registers are open-enclosed and contain instrumental, regulatory, representational, interactional, imaginative, and cognitive functions of information. An example of a case can be seen in Table 1 in speech discourse number 2, which says:

"This will be cheap, only 11 million yesterday, Pak Haji offered 10 million, but I still hold it if for you 11 million it is okay to maintain brotherly relations. "

Through the opening discourse "This will be cheap" and ending with the discourse "it is okay to connect brotherly relations," it is clear that there are three forms of consultative, causal, intimate registers. The consultative Register as a business register gives the idea of opening a transaction and ends with a causal register as an open register, leading to an intimate register as a form of intimacy and kinship. Thus, the discourse has an instrumental function capable of manipulating the environment so that events occur in a relaxed atmosphere even though there is a regulatory function. It regulates interactional events to maintain communication continuity by maintaining social relations. It opens up opportunities for other representational and imaginative functions.

The representational function means making statements in the form of delivering facts that tell actual events. As discussed in the text above, it is stated that 11 million has been offered. The discourse is a type of limited envelope register that gives a message of numbers without words. This type of limited envelope register becomes the entrance for representational functions and imaginative functions, meaning that a limited statement of facts with numbers without words opens up new ideas to follow the system or requests that are following their requests.

Other registers besides the three registers above used in the cattle trading arena are oratorical and deliberative registers. Oratorical registers are often called frozen. Professional speakers use these registers because the rules are solid, for example, as in the discourse on the speech of Table 1 data number 1 , the conversation between traders and farmers, which opens his conversation with the discourse:

\section{"Please, sir, please see! It is all special."}

Through this discourse, how firmly traders welcome buyers gently accompanied by information 'special all' which opens more open communication to be continued which is functionally cognitive and instrumental information. This information function provides information to be known, conative means that the speaker can follow the informed discourse according to the speaker's will. It leads to an instrumental register function to manipulate environmental conditions according to the speaker's expectations for transactional events to occur.

Furthermore, the deliberative Register is a formal register used in official situations to expand the conversation deliberately. It usually happens when related to official agencies, for example, government, banks, cooperatives, or other agencies. For example, there is data in Table 1, numbers 7-9. The following is an example of data number 7 in the conversation between bank officers and farmers. The conversation was started by a bank officer who officially asked the customer:

\section{"Please, sir, can I help you?”}

Even though it is only seven words, it is formal and has a referential register function that is emotive, conative, meaning that the conversation refers to a particular topic that can express feelings of joy, sadness, anger, and many others. Emotions are essential in turning them into a cognitive function that leads the interlocutor to follow what the speaker says. 


\section{B. The function of the Register in the Rhetoric of Cattle Trading Communication}

There are five forms of registers in the rhetoric of communication in the cattle trading arena, namely: consultative, casual, intimate, oratorical, deliberative. Each of the five registers contains functional instrumental, regulatory, representational, interactional, and imaginative discourses that lead to persuasion and tactics to defeat, subdue, restrain, and dominate.

An example of an instrumental function and a regulatory function can be seen in the following example of the opening discourse:

"This is going to be cheap," which ends with the discourse "it is okay to connect brotherhood relations."

The discourse functions instrumental because it can manipulate the environment to occur in a relaxed atmosphere. To be able to continue. As for an example of a regulatory function, it can be seen in the following discourse:

"Only 11 million yesterday, Pak Haji offered 10 million, but I still hold it, if for Jenengan 11 million it is okay to maintain brotherly relations."

The statement functions as a regulator, meaning that speakers begin to regulate interactional events to maintain the continuity of communication by maintaining social relationships. The two examples of register functions have hidden meanings that are not realized by the interlocutor, namely aspects of persuasion and stratagem. Persuasion is used to get around the opponent he said in order to follow his directions. When the interlocutor is willing to follow the directions, the speaker can defeat, subdue, restrain, and dominate.

The representational function means making statements in the form of delivering facts that tell actual events. As discussed in the text above, 11 million have been negotiated. The discourse gives a real message to persuade and get around the interlocutor carried away by the speaker's discourse without saying another word. This representational function can be developed with imaginative functions, meaning that from the limited statement of facts with numbers without words, it opens new ideas to follow the system or request that is following the request.

In addition to the three functions of the Register above in the rhetoric of cattle trade communication, there are also other functions: representational, interactional, personal, heuristic, neuritic, and informational. Some of these other functions indicate a form of persuasion and tactics to manipulate and even regulate. For more details and briefly review the register function in this discussion, it can be seen in Table 2 in the sub-chapter of research results.

\section{Symbolic Relations of Registered Discourse in the Rhetoric of Cattle Trading Communications}

Starting from the data on the results of research and discussion, it shows that socio-cultural practices in the cattle trading arena have hidden relationships that reveal meaning symbolic of the current socio-cultural phenomenon. The form of the register is dominated by five registers: consultative, casual, intimate, oratorical, deliberative. The five registers contain strategic function relations for persuasion, manipulation, and tactics in achieving domination goals.

The various forms of persuasion, manipulation, and tactics in Table 3 in the study results above show various forms of attractive offers but have reversed logic, meaning that they are different from the reality of the existing discourse. The success of the actors involved in building discourses to persuade, manipulate, and get around is strongly influenced by excess capital. It shows that the socio-cultural phenomenon in the cattle trading arena is a feudalistic relationship that places more capital as the main instrument in achieving the goal of domination.

In other words, the register discourse in the rhetoric of communication in the cattle trading arena has a symbolic meaning that the feudalistic relations glorifying more capital as the goal of the current socio-cultural phenomenon. In addition, the register discourse in the rhetoric of communication in the cattle trading arena also shows the existence of a symbolic meaning relation that places capital as more of a means to achieve the primary goal of domination. Efforts to achieve the main goal of domination, the discourse of registering communication rhetoric in the cattle trading arena shows the relation of symbolic meaning that discourses on reverse communication rhetoric as a model role for modern capitalist socio-cultural phenomena.

\section{CONCLUSION}

By examining registers in the rhetorical style and discourse of beef trading arena communication, the following conclusions can be drawn: 1 . The form of registers in communication rhetoric at the cattle trading arena is dominated by consultative, casual, intimate, oratorical, deliberative registers; 2 . The functions of the register are: representational, interactional, personal, heuristic, neuritic, instrumental, interactive, informational, emotive, conative, and imaginative as persuasi $\neg$ on efforts, tactics to manipulate, defeat, subdue, even regulate or dominate; 3 ). The register in the rhetoric of communication in the cattle trading arena contains the relation of symbolic meaning to the modern capitalist sociocultural 
phenomenon, which is characterized by the phenomenon of feudalistic relations that still glorify excess capital and use the rhetoric of reverse communication as a means to achieve the goal of domination.

\section{REFERENCES}

[1] Alberico \& Loisa. (2019). Retorika Deliberatif Selebgram dalam Motivasi Audiens Melalui Media Sosial'. Jurnal Koneksi. Vol.3.No.1 Juli. hlm.236-243.

[2] Aminuddin. (1995). Pengantar Apresiasi Karya Sastra. Bandung: Sinar Baru Algensindo.

[3] Badudu, Zain. (1994). Kamus Umum Bahasa Indonesia. Jakarta: Pustaka Sinar Harapan.

[4] Barker, Chris. (2011). Cultural Studies, Teori dan Praktik. (Terjemah:Nurhadi). Yogyakarta: Pustaka Pelajar.

[5] Black, James A. \& Dean J. Champion. (1992). Metode dan Masalah Penelitian Sosial. Terjemah E.Koeswara, dkk. Bandung: Remaja Rosdakarya.

[6] Chaer, A. (2010). Kesantunan Berbahasa. Jakarta. Rineka Cipta.

[7] Chaer, Abdul dan Leonie Agustina. (1995). Sosiolinguistik. Jakarta: Rineka Cipta.

[8] Gayatri A/P Marimothu dan Rohaidah Kamaruddin (2018). Pemerolehan dan Penguasaan Leksikal Bahasa Melayu Kanak-Kanak India di Persekolahan. Pertanika Journal Mawangsa 5 (1): 413-421.

[9] Harun Joko Prayitno (2009). Tindak Kesantunan Berbahasa Dalam Dialektika Pembelajaran Pragmatik: Berdaya, Berorientasi, dan Berstrategi Kesantunan Positif'. Prosiding Seminar Nasional Prasasti II. Kajian Pragmatik dalam Berbagai Bidang.

[10] Hendrikus dalam Rajiyem (2005). Sejarah Perkembangan Retorika. Jurnal Humaniora, Vol. 17.No.2. hlm. 142-153.

[11] Kandi, Umar (2017). Teori Kekuasaan Michel Foucault: Tantangan bagi Sosiologi Politik. Jurnal Al Khitabah. Vol. 3, No. 1 diunduh 1 Juni 2017, hlm. 118.

[12] Keraf, Gorys. 1990. Diksi dan Gaya Bahasa. Jakarta: Gramedia.

[13] Kutha Ratna, Nyoman. 2009. Paradigma Sosiologi Sastra. Yogyakarta: Pustaka Pelajar.

[14] Krisdimanto, Nanang (2014). Pierre Bourdieu, Sang Juru Damai. Kanal. Vol. 2. No. 2. Maret. hlm. 203.

[15] Magnis Suseno, Frans. (2001). Pemikiran Karl Marx. Jakarta: Gramedia.

[16] Moleong, Lexy J., 1991. Metodologi Penelitian Kualitatif. Bandung: Remaja Rosda Karya.

[17] Nababan, P.W.J. 1993. Sosiolinguistik: Suatu Pengantar. Jakarta: Gramedia Pustaka Utama.

[18] Ningeh, Martha.I. (2010). Retorika dan Penggunaannya dalam Berbagai Bidang. Jurnal Persisi, Vol.6, No,12, Juli - Desember. hlm. 61.

[19] Patria, Nezar \& Andi Arif. (2015). Antonio Gramsci, Negara dan Hegemoni. Yogyakarta: Pustaka Pelajar.

[20] R. Kunjana Rahardi, (2017). Manifestasi Fenomena Ketidaksantunan Prakmatik Berbahasa Berasaskan Budaya Indonesia. Journals Pertanika, Mahawangsa 4 (1):147-166.

[21] Ritzer, George \& Douglas J.Goodman. Tterjemahan Nurhadi. (2009). Teori Sosiologi dari Sosiologi Klasik sampai Perkembangan Mutakhir Teori Sosial Postmodern. Yogyakarta: Pustaka Pelajar.

[22] Soekanto, Soerjono. (1990). Sosiologi Suatu Pengantar. Jakarta: Rajawali Pers.

[23] Soeparno. (2018). Dasar-Dasar Linguistik Umum. Yogyakarta: Tiara Wacana.

[24] Skeggs, Beverley. (2013). Perasaan Kelas (Sosial): Afeksasi dan Budaya dalam Penciptaan Relasi Kelas (sosial), dalam The Wiley-Blackwell Companion to Sosiologi. Yogyakarta: Pustaka Pelajar.

[25] Sulistyarini, Dhanik, et. al. (2020). Buku Ajar Retorika. Serang Banten: A.A.Rizky.

[26] Sutopo, H.B. (2006). Metodologi Penelitian Kualitatif: Dasar-Dasar Teori dan Terapannya dalam Penelitian. Surakarta: Universitas Sebelas Maret.

[27] Sutrisno \& Ida Wiendijarti (2014). Kajian Retorika Untuk pengembangan Berpidato. Jurnal Komunikasi. Vol.12. No. 1, Januari-April 2014. hlm.70-84.

[28] Suwito. (1985). Sosiolinguistik Pengantar Awal. Surakarta: Universitas Sebelas Maret.

[29] _. (1983). Pengantar Awal Sosiolinguistik, Teori dan Problema. Surakarta: Henary Offset.

[30] Wuwur Dori Hendrikus. (2017). Retorika Terampil Berpidato, Berdiskusi, Berargumen, Bernegosiasi. Yogyakarta: Kanisius. 
